\title{
EXPLORING THE RELATIONSHIP BETWEEN PROCEDURAL JUSTICE AND INNOVATIVE WORK BEHAVIOR IN HOSPITALITY INDUSTRY
}

\author{
Noerchoidah $^{1}$, Dhyah Harjanti ${ }^{2}$ \\ ${ }^{1}$ Universitas Airlangga, Surabaya; Surabaya Merdeka University, Surabaya, Indonesia \\ ${ }^{2}$ Universitas Airlangga, Surabaya; Petra Christian University, Surabaya, Indonesia \\ Email: ${ }^{1}$ noerchoidah1969@gmail.com; ${ }^{2}$ dhyah@petra.ac.id
}

\begin{abstract}
The purpose of this study is to examine the relationship between procedural justice, knowledge sharing and innovative work behavior. The research model and hypothesis were developed from related literature. The data was collected through survey method on 297 supervisors of four and five star hotels in East Java, Indonesia. The obtained data from the questionnaire were tested with Partial Least Square (PLS) to investigate the research model. The results confirm that procedural justice has positive impact on knowledge sharing. While the effect of knowledge sharing on innovative work behavior is another finding of this research. The implications of this study are discussed in the conclusions section of the study.
\end{abstract}

Keywords: Innovative work behavior, knowledge collecting, knowledge donating, procedural justice.

\section{Introduction}

In today's highly competitive market environment, rapid technological advances, and globalization are challenges to the hospitality industry. This trend urges organizational experts to investigate organizational factors that have a strong impact on employee innovative work behavior (Hammond, Neff, Farr, Schwall \& Zhao, 2011). The hotel's ability to improve superior service innovation is a key factor in guest satisfaction and loyalty. The hotel's ability to innovate is crucial to achieve a sustainable competitive advantage (Tajeddini, 2010). In this paper, it analyses what hotels should do to encourage the innovative behavior of their employee services.

The organizational justice is very important for employees to get fair treatment from organizations in the workplace (Shin, Du \& Choi, 2015; Ouyang, Sang, Li \& Peng, 2015). The organizational justice is related to employees' perceptions of justice in the organization. It is basically an employee's perception of how justly they are treated in the organization. The organizational justice consists of three components, namely distributive justice, procedural justice, and interactional justice (Kerwin, Jordan \& Temer, 2015; $\mathrm{He}, \mathrm{Zu} \& \mathrm{Zheng}, 2014)$. The distributive justice refers to justice about the number and awarding perceived among individuals (Biswas, Varma \& Ramaswami, 2013; Ghosh, Sekiguchi \& Gurunathan, 2017). The procedural justice relates to justice over the procedures used in decision making (Campbell, Perry, Maertz, Allen \& Griffeth, 2013; He et al., 2014). The interactional justice refers to perceived fairness of communication and interactional treatment (Karkou- lian, Assaker, \& Hallak, 2016; He et al., 2014). The empirical results of Karkoulian et al. (2016) found that of three components of organizational justice, only procedural justice, and interactional justice positively affect the organization's sustainability, while distributive justice does not. This research examines the effects of perceived fairness in exchanges between employees and organizations, rather than exchanges between superiors and subordinates. It focuses on the procedural justice based on the empirical and conceptual reasons mentioned earlier.

With regard to knowledge sharing and innovative work behavior, superior service quality is a major factor in delivering guest satisfaction and loyalty. The hotel could cultivate innovative behavior of employee by enhancing employee knowledge sharing to meet demands and provide superior service (Hallin \& Marnburg, 2008; Kim \& Lee, 2012). Therefore, align with Hu, Horng and Sun (2009); the behavior of individual knowledge sharing is a key factor in the innovative behavior of employees in the hospitality industry. The knowledge sharing refers to the exchange of information, qualities, skills, and feedback to create new knowledge or ideas (Wang \& Noe, 2010; Kim \& Lee, 2013). However, employees are often reluctant to share knowledge for fear of reducing their chances of promotion or because it takes time and energy that is not compensated (Kim \& Lee, 2010; 2012; Welschen, Todorova \& Mills, 2012; Kim, Han, Son \& Yun, 2017). Most studies use knowledge sharing as unidimensional construct, with only several exceptions (Tohidinia \& Mosakhani, 2010; Karkoulian, Harake \& Messarra, 2010; Kim \& Lee, 2013; Tangaraja, Rasdi, Ismail \& Samah, 2015; 
Harjanti \& Noerchoidah, 2017). This research uses multidimensional construct of knowledge sharing, i.e.: knowledge collecting and knowledge donating. The knowledge collecting is consulting with colleagues to learn from them, while knowledge donating is providing knowledge, including the desire of employees to communicate with colleagues. These two dimensions are conceptually different. Therefore, they are considered as two separate variables in our study.

According to Yuan and Woodman (2010), innovative work behavior is a complex process involving three stages, including idea creation, followed by finding support and execution of new ideas. Slåtten, Svensson and Sværi (2011) also describes innovative work behavior as a deliberate creation, introduction, and application of new ideas in the work, group, or organization roles, in order to gain performance benefits of roles, groups, or organizations.

The knowledge sharing and innovative work behavior have also been investigated in relation to procedural justice. The findings suggest that organizational efforts to be objective during the decisionmaking process (i.e., procedural justice) can positively influence knowledge sharing and innovative work behavior (Kim \& Park, 2017; Kim \& Lee, 2013; Akram, Haider \& Feng, 2016; Akram, Lei, Haider, Hussain, \& Puig, 2017). However, different findings from Almansour and Minai (2012) show procedural justice does not have significant effect on innovative work behavior. Based on these identifications and explanations refers to theoretical studies and empirical findings, there are differences of opinion or research gap from various previous studies. Therefore, this study intends to review the difference of the results of the prior study.

Although the previous studies have examined the four research constructs separately (procedural justice, knowledge collecting, knowledge donating, and innovative work behaviors) however, there is still a lack of comprehensive research and simultaneous investigation of relationships between constructs. Therefore, the current study aims to examine procedural justice, knowledge collecting, knowledge donating, and the supervisor innovative work behavior comprehensively. It studies on four stars and five stars hotels in East Java, Indonesia. It focuses on East Java because of its unique characteristic. As a transit area between Central Java and Bali, East Java become main tourism attraction and destination, as well as center of agrobusiness and manufacturing. Moreover, the four and five stars hotels have rigid standard operational procedure, consequently their success depend on their innovative activities.
This study examines the relationship between construct using supervisors of four and five star hotels as samples, since supervisors have more involvement in the process of generating creativity for innovation and corporate effectiveness. The innovative work behavior of supervisors is important to examine, because the innovations made in the hospitality industry could easily imitated. This industry is likely to produce homogeneous products by creating similar service offerings. In order to provide superior service quality to hotel guests and to gain a sustainable competitive advantage, hotels are increasingly relying on individual innovations by employees demonstrated in innovative work behavior in their products, processes, methods, and work. The quality of service provided affects the satisfaction and loyalty of guests.

\section{Social Exchange}

This study uses social exchange theory (Blau, 2017) to support the relationship between the four constructs. Social exchange theory is used to comprehend the employee behavior in the workplace. Social exchange refers to transactions or relationships between two parties or more (e.g, relationships between employees and organizations), involving unspecified future obligations through mutual exchange of resources (e.g, reciprocal interchange) (Zhang, LePine, Buckman \& Wei, 2014). If the organization is objective and procedures are transparent then employees are likely to give positive action. On the contrary, if employees perceive the procedure used in decisionmaking is unfair then the employee will behave negatively.

\section{Organizational Justice}

The justice is one of the important factors that shape the actions of individual employees within the organization (Heidari \& Saeedi, 2012; Usmani \& Jamal, 2013). An objective management leads to a better social interaction and overall organizational effectiveness (Heidari \& Saeedi, 2012). This has an effect on the ways employees show work behavior and work attitude that ultimately yields positive results if treated fairly or, negative if otherwise (Usmani \& Jamal, 2013). Therefore, justice has profound and significant implications for individuals and organizations as a whole (Yesil \& Dereli, 2013).

The distributive justice is derived from Adam's equity theory which argues that employees consider the appropriate input-output ratio (Colquitt, LePine, Piccolo, Zapata, \& Rich, 2012). The input refers to time and effort. Whereas output refers to rewards, 
such as promotion, payments, recognition, equipment or other work related resources that assist employees in job duties or maintaining overall wellbeing. Employees will perceive distributive justice if their contribution of time and effort to the organization is appropriately compensated through awards and recognition (Biswas et al., 2013). In other words, they consider that they are receiving an appropriate return on their resource investment.

The procedural justice refers to employee perceptions of fairness of rules and procedures used to determine the outcomes received at work (Campbell et al., 2013; Suliman \& Kathairi, 2013). According to McShane and Glinow (2010); Li and Cropanzano (2009), procedural justice deals with the fairness of the procedure used to distribute the results. Lavental (1980) (in Colquitt, 2012) states that procedural justice is important, and suggests several criteria to evaluate fairness in a resource allocation process, namely representativeness, accuracy, consistency, suppression bias, correctability, and ethicality.

Based on the perspective of social exchange theory, when employees consider the organizational procedures is just, their trust and confidence to be more involved in the organization will augmented. Thenceforward, they will show positive attitudes and behaviors in their work (Biswas et al., 2013). The interactional justice refers to the quality of the relationships between individuals within the organization, or the fairness of interpersonal treatment received during the execution of the procedure. This relates to aspects of the communication process between source and recipient of justice, such as treating employees with dignity, courtesy, honesty, and respect (Karkoulian et al., 2016; He et al., 2014).

\section{Knowledge Sharing}

The employee's knowledge assets are indispensable for the survival and competitive advantage of the organization (Safa \& Solms, 2016; Yesil \& Dereli, 2013). In order to provide guest satisfaction and continuous innovation, the hotel can enhance organizational effectiveness through knowledge sharing (Yang, 2010). Knowledge sharing is crucial in implementing knowledge management within the organization (Wang \& Noe, 2010; Kim \& Lee, 2010, 2012; Park, Son, Lee \& Yun, 2009). It is a mechanism in which knowledge can be disseminated between individuals. Through the transmission of knowledge to facilitate new actions so as to contribute value to existing knowledge within the organization (Wang \& Noe, 2010). Knowledge sharing is the mechanism by which knowledge can be disseminated between individuals. Through the transmission of knowledge, the company facilitates new actions, thereby contributing value to the existing knowledge within the organization (Wang \& Noe, 2010; Yang, 2010; Harrington \& Ottenbacher, 2011).

Knowledge sharing refers to social interaction, which involves exchanging employee knowledge, experience, and skills through an entire department or organization to help others and to collaborate with others to solve problems, develop new ideas, or implement policies or procedures (Kumar \& Che Rose, 2012; Tangaraja et al., 2015). Knowledge sharing occurs when a person is willing to collect and donate knowledge (Tohidinia \& Mosakhani, 2010; Mat, Yaacob, \& Melhem, 2016). Knowledge collecting refers to the individual's willingness to learn from his/her colleagues in developing new abilities. Knowledge donating refers to the willingness to assist other peers in developing new capabilities.

When employees aware that having high levels of skill and ability can improve work efficiency and increase productivity, they are more likely to share knowledge. They will collect skills, experience, and knowledge, as well as, donate knowledge to colleagues (Magnini, 2008). However, these knowledgesharing processes can be difficult and time consuming. Moreover, there is a risk of loss of knowledge power (Kim \& Lee, 2013). Knowledge collecting and knowledge donating activities require intrinsic motivation. Whereas most previous research consider knowledge transfer as a single feature of knowledge sharing while and tend to ignore knowledge collecting (Goh \& Sandhu, 2014). This research studies knowledge sharing as a combination of knowledge collecting and knowledge donating.

The employees can gain knowledge from their work experience and failures. This valuable knowledge enables them to earn better salary and career opportunities. As a result, many employees prefer collecting rather than donating their knowledge. There are barriers to share knowledge when the knowledge sharing process is complex (He \& Wei, 2009), because employees are more interested in meeting performance standards than in knowledge donating.

\section{Innovative Work Behavior}

The individual innovative behavior is essential for competitive advantage and long-term success of the company. The hospitality industry requires creative employees to generate new ideas about work processes, methods, services, or products (Hon, 2011). According to Larson (2011); Gong, Cheung, Wang and Huang (2012), all innovations begin with 
creative ideas and creativity as the generation of new ideas. In the hospitality industry, creative thinking is critical to improve guest satisfaction and provide superior service (Hallin \& Marnburg, 2008).

However, generally formal roles or employee contracts are not explicitly expect their employees to perform innovative work behavior. Innovative work behavior is purely an extra-role behavior (Zhang \& Begley, 2011; Baer, 2012; Abstein \& Spieth, 2014). Therefore, most organizational reward systems are not formally recognize it (Baer, 2012). The employees involvement in innovative work behavior are likely bring benefit for organization and group. Even for the individual employee, by enabling him/her to perform their task more effectively. Innovative work behaviors are more likely to be the result of an employee's intrinsic motivation, meaning employees decide for themselves whether to engage in an innovative work behavior or not.

This study focuses on three-stage model of innovative work behavior, namely idea generation, promotion, and idea implementation (Yuan \& Woodman, 2010; Krizaj, Brodnik, \& Bukovec, 2014; Thurlings, Evers, \& Vermeulen, 2015). Idea generation refers to generating new and useful ideas for problem solving within organizations (De Jong \& Den Hartog, 2010; Hon, 2011). Promotion refers to efforts to gain support from colleagues and organizations. The realization of ideas refers to the implementation of ideas that have been developed and promoted to be able to provide solutions and disseminate their use throughout the organization.

\section{Hypothesis}

Most of previous research on organizational justice finds that employees' perceptions of procedural justice are related to the procedures used in determining organizational outcomes (e.g., rule-making, punishment) (Suliman \& Kathairi, 2013). When the expectations of employees to be treated fairly by the organization are met, then there is an intrinsic drive to demonstrate extra-role behavior, such as sharing skills and expertise with co-workers (Biswas et al., 2013). The organization procedural justice has a direct positive impact on knowledge sharing of employees (Yesil \& Dereli, 2013; Akram et al., 2017). The procedural justice influenced the process of knowledge sharing, namely knowledge collecting and knowledge donating (Tohidinia \& Mosakhani, 2010; Wang \& Noe, 2010; Simmons, 2011; Young, 2012; Tsai, Horng, Liu \& Hu, 2015). Based on previous researches, it is proposed hypothesis as follows:

$H_{1}$ : Procedural justice has a positive effect on knowledge collecting.

\section{$\mathrm{H}_{2}$ : Procedural justice has a positive effect on know-} ledge donating.

A number of studies have discussed the relationship between procedural justice and innovative work behavior (Akram et al., 2016; Kim \& Park, 2017; Streicher, Jonas, Maier, \& Frey, 2012; Almansour \& Minai, 2012). The relationship between procedural justice and innovative work behavior is significant, both directly and indirectly (Kim \& Lee, 2013; Agarwal, 2014; Momeni, Ebrahimpour \& Ajirloo, 2014; Akram et al., 2016; Kim \& Park, 2017). The procedural justice focuses on the sensibleness of decision making (Cropanzano, Bowen, \& Gilliland, 2007 in Yesil, \& Dereli, 2013). Based on the literature on organizational justice (Kim \& Park, 2017), the procedural justice component can affect innovative work behavior. Kim and Park, 2017 states that the extent to which employees feel their expectations have been met (or not met) can influence their obligations to employers. The perceived obligation affects the employee's innovative work behavior. This study presumes procedural justice has an effect on innovative work behavior. It formulates the hypothesis in this manner:

$H_{3}$ : Procedural justice has a positive effect on innovative work behavior.

The employee knowledge sharing, namely knowledge collecting and knowledge donating, contribute to the adoption of new ideas that affect employee innovative work behavior (Hu et al., 2009; Kim \& Lee, 2013). Empirical research results of knowledge collecting and knowledge donating behavior significantly influence innovative work behavior ( $\mathrm{Hu}$ et al., 2009; Kim \& Lee, 2013). It proposes that hotel employees' willingness to knowledge collecting and knowledge donating to colleagues positively relate to their innovative work behavior. Based on previous research and empirical evidence, it is believed that knowledge collecting and knowledge donating of hotel supervisor can improve innovative work behavior. Therefore, it suggests the hypothesis as follows:

$H_{4}$ : Knowledge collecting positively affects the innovative work behavior.

$H_{5}$ : Knowledge donating positively affects innovative work behavior.

\section{Research Method}

It distributes 342 questionnaires to supervisors at four stars and five stars hotels in East Java of Indonesia. Only 323 of them are returned and 297 questionnaires could be processed for analysis. Respon- 
dents consisted of 190 men $(63,97 \%)$ of men and 107 women $(36.03 \%)$. The sample of this research was obtained by using non-probability sampling technique.

For measurement, the procedural justice items are derived from Al-Zu'bi's concept (2010). The procedural justice sample item is along these lines: "The procedures in the policy making in my work department are based on complete and accurate information". The knowledge collecting items are modified from Kim \& Lee (2013). The knowledge collecting sample items are as follows: "I ask my colleagues in the department to teach me their skills." The knowledge donating items are adapted from Kim and Lee's concept (2013). The sample item is as follows: "I share information which I have with colleagues in my department". The innovative work behavior items are developed from De Jong and Den Hartog (2010). The sample item of innovative work behavior is as follows: "I have freedom take initiative to convey creative ideas at work".

Table 1

Results of the Measurement Model

\begin{tabular}{|c|c|c|c|c|c|}
\hline Construct & Items & $\begin{array}{c}\text { Factor Loading }(t) \\
(>0.7)\end{array}$ & $\begin{array}{c}\text { Cronbach's } \alpha \\
(>0.7)\end{array}$ & $\begin{array}{c}\mathbf{C R} \\
(>0.7) \\
\end{array}$ & $\begin{array}{l}\text { AVE } \\
(>0.5)\end{array}$ \\
\hline \multirow{4}{*}{ Procedural Justice } & $X_{.2}$ & $0.769(23.389)$ & \multirow{4}{*}{0.821} & \multirow{4}{*}{0.882} & \multirow{4}{*}{0.652} \\
\hline & $X \cdot 3$ & $0.832(36.280)$ & & & \\
\hline & $X .4$ & $0.831(35.329)$ & & & \\
\hline & $X .5$ & $0.795(23.262)$ & & & \\
\hline \multirow{6}{*}{ Knowledge Collecting } & $Y_{1.2}$ & $0.744(18.715)$ & \multirow{5}{*}{0.793} & \multirow{5}{*}{0.858} & \multirow{5}{*}{0.547} \\
\hline & $Y_{1.3}$ & $0.771(20.155)$ & & & \\
\hline & $Y_{1.4}$ & $0.727(20.248)$ & & & \\
\hline & $Y_{1.5}$ & $0.731(18.751)$ & & & \\
\hline & $Y_{1.6}$ & $0.725(17.823)$ & & & \\
\hline & $Y_{2.1}$ & $0.804(32.203)$ & \multirow{5}{*}{0.897} & \multirow{5}{*}{0.924} & \multirow{5}{*}{0.709} \\
\hline \multirow{4}{*}{ Knowledge Donating } & $Y_{2.2}$ & $0.833(41.073)$ & & & \\
\hline & $Y_{2.4}$ & $0.846(29.894)$ & & & \\
\hline & $Y_{2.5}$ & $0.862(47.110)$ & & & \\
\hline & $Y_{2.6}$ & $0.864(43.190)$ & & & \\
\hline \multirow{7}{*}{$\begin{array}{c}\text { Innovative Work } \\
\text { Behavior }\end{array}$} & $Y_{3.1}$ & $0.766(27.097)$ & \multirow{7}{*}{0.874} & \multirow{7}{*}{0.902} & \multirow{7}{*}{0.57} \\
\hline & $Y_{3.2}$ & $0.788(29.882)$ & & & \\
\hline & $Y_{3.3}$ & $0.813(34.948)$ & & & \\
\hline & $Y_{3.4}$ & $0.739(23.929)$ & & & \\
\hline & $Y_{3.6}$ & 0.702 (21.889) & & & \\
\hline & $Y_{3.7}$ & 0.743 (26.889) & & & \\
\hline & $Y_{3.8}$ & $0.728(22.008)$ & & & \\
\hline
\end{tabular}

Table 2

Mean, Standard Deviation, and Correlations among Study Constructs

\begin{tabular}{lccccccc}
\hline \multicolumn{1}{c}{ Construct } & Mean & SD & AVE & $\mathbf{1}$ & $\mathbf{2}$ & $\mathbf{3}$ & $\mathbf{4}$ \\
\hline Procedural Justice & 3.940 & 0.684 & 0.499 & 1 & & & \\
Knowledge Collecting & 4.059 & 0.628 & 0.447 & 0.358 & 1 & & \\
Knowledge Donating & 4.203 & 0.579 & 0.570 & 0.432 & 0.557 & 1 & \\
Innovative Work Behavior & 4.000 & 0.674 & 0.421 & 0.564 & 0.533 & 0.645 & 1 \\
\hline
\end{tabular}

All items are measured using a Likert scale of 15 , ranging from strongly disagreeing (1) to strongly agreeing (5). In this research, it performs a two-stage data analysis (Hair, Black, Babin \& Anderson, 2010), started with evaluate the reliability and validity of data. Then, it uses the least partial least squares technique to test the hypothesis (Chin et al., 2003 in Urbaach, \& Ahlemann, 2010).

\section{Result}

In the first stage, it assesses the construct reliability using Cronbach's alpha and composite reliability calculation. From 35 item indicators, it found 14 items are not reliable. Therefore, these indicators are eliminated from further analysis. Table 1 presents the individual item reliability of each standardized factor loading, the composite reliability (CR) and Cronbach's $\alpha$ after these indicators eliminated.

Table 2 shows the mean, standard deviation, and correlations among the constructs, with the square root of the AVE on the diagonal. 
Furthermore, Table 3 shows that the validity of the construct, reliability, convergent validity, discriminant validity, and unidimensionality are met.

Table 3

Item Loading and Cross-loading

\begin{tabular}{|c|c|c|c|c|}
\hline Items & $\begin{array}{c}\text { Procedural } \\
\text { Justice }\end{array}$ & $\begin{array}{l}\text { Knowledge } \\
\text { Collecting }\end{array}$ & $\begin{array}{c}\text { Knowledge } \\
\text { Donating }\end{array}$ & $\begin{array}{c}\text { Innovative } \\
\text { Work } \\
\text { Behavior } \\
\end{array}$ \\
\hline$X_{\cdot 2}$ & 0.769 & 0.167 & 0.287 & 0.470 \\
\hline$X .3$ & 0.832 & 0.231 & 0.313 & 0.484 \\
\hline$X_{\cdot 4}$ & 0.831 & 0.253 & 0.319 & 0.442 \\
\hline$X .5$ & 0.795 & 0.258 & 0.349 & 0.414 \\
\hline$Y_{1.2}$ & 0.226 & 0.744 & 0.356 & 0.370 \\
\hline$Y_{1.3}$ & 0.176 & 0.771 & 0.329 & 0.348 \\
\hline$Y_{1.4}$ & 0.189 & 0.727 & 0.433 & 0.305 \\
\hline$Y_{1.5}$ & 0.221 & 0.731 & 0.402 & 0.345 \\
\hline$Y_{1.6}$ & 0.225 & 0.725 & 0.334 & 0.381 \\
\hline$Y_{2.1}$ & 0.317 & 0.412 & 0.804 & 0.426 \\
\hline$Y_{2.2}$ & 0.356 & 0.494 & 0.833 & 0.538 \\
\hline$Y_{2.4}$ & 0.324 & 0.374 & 0.846 & 0.407 \\
\hline$Y_{2.5}$ & 0.299 & 0.390 & 0.862 & 0.443 \\
\hline$Y_{2.6}$ & 0.350 & 0.413 & 0.864 & 0.468 \\
\hline$Y_{3.1}$ & 0.385 & 0.365 & 0.366 & 0.766 \\
\hline$Y_{3.2}$ & 0.461 & 0.364 & 0.374 & 0.788 \\
\hline$Y_{3.3}$ & 0.476 & 0.355 & 0.437 & 0.813 \\
\hline$Y_{3.4}$ & 0.355 & 0.384 & 0.422 & 0.739 \\
\hline$Y_{3.6}$ & 0.397 & 0.455 & 0.475 & 0.702 \\
\hline$Y_{3.7}$ & 0.482 & 0.297 & 0.394 & 0.743 \\
\hline$Y_{3.8}$ & 0.394 & 0.278 & 0.411 & 0.728 \\
\hline
\end{tabular}

After verifying the validity and reliability of the construct and all of its indicators, it continues to the second stage of data analysis, i.e: testing the hypotheses. It utilizes partial least squares techniques, initiating by examining the variance measured $\left(R^{2}\right)$ by the antecedent constructs. This study applies Cohen's benchmark to interpret the results of $R^{2}$, namely 0.02 , 0.13 , and 0.26 as the small, medium, and large variance, in that order. Then, it employs the bootstrapping and compute the $t$-values to acquire the significance of the path coefficients and total effects. the summary of hypothesis test results is presented in Figure 1 and Table 4.

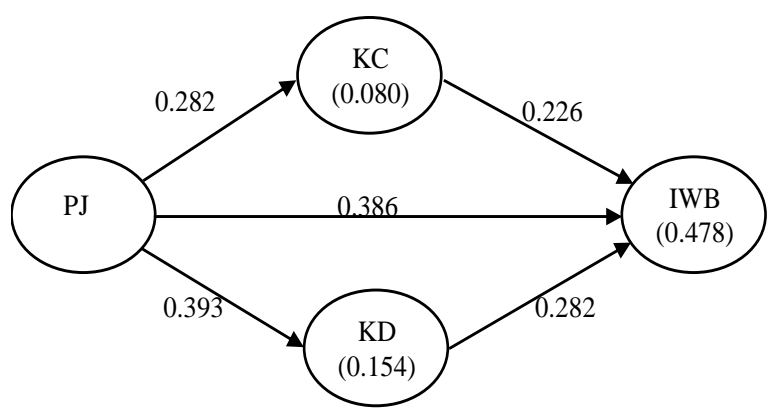

Figure 1. The result of inner loading
Table 4

Hypothesis Test Result

\begin{tabular}{ccccc}
\hline Hypothesis & Path & $\begin{array}{c}\text { Path } \\
\text { Coefficient }\end{array}$ & t-value & Results \\
\hline$H_{1}$ & PJ $\rightarrow$ KC & 0.282 & 3.613 & Supported \\
$H_{2}$ & PJ $\rightarrow \mathrm{KD}$ & 0.393 & 5.847 & Supported \\
$H_{3}$ & $\mathrm{PJ} \rightarrow \mathrm{IWB}$ & 0.386 & 6.644 & Supported \\
$H_{4}$ & $\mathrm{KC} \rightarrow \mathrm{IWB}$ & 0.226 & 4.117 & Supported \\
$H_{5}$ & $\mathrm{KD} \rightarrow \mathrm{IWB}$ & 0.282 & 5.533 & Supported \\
\hline
\end{tabular}

Table 4 shows that all coefficient path scores or inner model shown by $t$-statistic values are greater than 1.96. Therefore, it can conclude that the procedural justice significantly influences knowledge collecting $\left(H_{I}\right)$ as well as knowledge donating $\left(H_{2}\right)$. Furthermore, the results of this study confirm that procedural justice has a positive effect on innovative work behavior $\left(H_{3}\right)$. Moreover, knowledge collecting positively affect the innovative work behavior $\left(H_{4}\right)$ and knowledge donating positively affect the innovative work behavior $\left(H_{5}\right)$ significantly.

\section{Discussion}

This current study explores the effect of procedural justice on two types of knowledge sharing (knowledge collecting and knowledge donating) as well as the innovative work behavior of hotel supervisors. The findings of this study conclude that procedural justice influences knowledge collecting and knowledge donating. The results of this study support the previous researchs (Tohidinia \& Mosakhani, 2010; Yesil \& Dereli, 2013; Akram et al., 2017).

Another finding of this research is that procedural justice influences innovative work behavior. It implies that when supervisors perceive fairness in procedural justice, they are more willing to be innovative, share more new ideas and discuss with other colleagues, then implement those new ideas in the workplace. The results of this study are consistent with the results of previous studies (Momeni et al., 2014: Kim \& Lee, 2013; Hsu \& Wang, 2015; Akram et al., 2016). However, this study shows dissimilar results with previous research by Almansour and Minai (2012) which reveals that procedural justice has no significant effect on innovative work behavior. The dissimilarity may occur due to differences in environmental and cultural factors.

As regards to the relationship between two types of knowledge sharing and innovative work behavior, the results show that the willingness of supervisors to do knowledge collecting and knowledge donating has a significant positive effect on their innovative work behavior. This indicates that knowledge collecting and knowledge donating plays an important role in 
encouraging innovative work behavior supervisor. The knowledge donating appears has a stronger effect on innovative work behavior than the knowledge collecting do. The results of this study indicate that hotel management should encourage knowledge sharing behavior, especially knowledge collecting to improve their employee innovative work behavior. The significant positive relationship between knowledge collecting and knowledge donating to innovative work behavior was also found by $\mathrm{Hu}$ et al. (2009), Kim and Lee (2013), and also by Akram, Lei, Haider, and Hussain (2018). Hu et al. (2009) emphasis the role of employee knowledge sharing (symbiosis, reputation, and altruism) as determinants of innovative behavior of international hotel employees in Taiwan. Furthermore, Mura, Lettieri, Radaelli, and Spiller (2013) found a positive influence of knowledge sharing behavior to employee innovative behavior, in the form of tendency and capacity to promote and implement new ideas.

\section{Conclusion}

There are several limitations in this study. First, this study is a cross-sectional study. Therefore, its ability to establish a definite causal relationship between research variables is limited. We suggest a longitudenal study can be performed in the future for the establishment of a better causal relationship between independent and dependent variables. Secondly, this study only analyses three variables, namely: procedural justice, knowledge collecting, and knowledge donating, that have an effect on innovative work behavior. However, there are numbers of other factors related to the organization and employees that hypothetically influenced innovative work behavior.

From a practical perspective, this study provides some suggestions to support hotel management in encouraging procedural justice, knowledge sharing, and innovative work behavior of supervisor. First, the management should create organizational climate oriented towards procedural justice, knowledge sharing, with special attention to supervisors' willingness to collect and donate their knowledge with colleagues to learn new capabilities and to improve their innovative work behavior (Yang, 2010). Second, encourage the supervisors' willingness to perform knowledge collecting and knowledge donating by facilitating learning orientation. The leaders should encourage voluntary knowledge collecting and donating regarding to work, experience, expertise, knowledge, skills, and contextual information to improve service quality and guest satisfaction, in addition to enhance supervisor innovative work behavior. Third, the results of this study also imply that managers should be aware that the supervisor's readiness to do knowledge donating, including experience related to work, skills, knowledge, skills, and contextual information to other coworkers, is more important than the willingness to collect knowledge for the improvement of innovative work behavior.

\section{References}

Abstein, A. \& Spieth, P. (2014). Exploring HRM meta-features that foster employees' innovative work behaviour in times of increasing work-life conflict. Creativity and Innovation Management, 23(2), 211-225.

Agarwal, A. U. (2014). Linking justice, trust and innovative work behaviour to work engagement. Personnel Review, 43, 41-73.

Akram, T., Haider, M. J., \& Feng, Y. X. (2016). The effects of organizational justice on the innovative work behavior of employees: An empirical study from China. Journal of Creativity and Business Innovation, 2, 114-126.

Akram, T., Lei, S., Haider, M., \& Hussain, S. T. (2018). Exploring the impact of knowledge sharing on the innovative work behavior of employees: A study in China. International Business Research, 11(3), 186-194.

Akram, T., Lei, S., Haider, M., Hussain, S. T., \& Puig, L. (2017). The effect of organizational justice on knowledge sharing: An empirical evidence from the Chinese telecommunication sector. Journal of Innovation \& Knowledge, 2, 134-145.

Almansour, Y. M., \& Minai, M. S. (2012). The relationship between organizational justice component and innovative behavior in Arab society. Evidence from government department in Jordan. Middle-East Journal of Scientific Research, 12(1), 46-51.

Al-Zu'bi, H. A. (2010). A study of relationship between organizational justice and job satisfaction. International Journal of Business and Management, 5(12), 102-109.

Baer, M. (2012). Putting creativity to work: The implementation of creative ideas in organizations. Academy of Management Journal, 55(5), 1102-1119.

Biswas, S., Varma, A., \& Ramaswami, A. (2013). Linking distributive and procedural justice to employee engagement through social exchange: A field study in India. International Journal Human Resources Management, 24, 1570-1587.

Blau, P. M. (2017). Exchange and power in social life. New York: Wiley. 
Campbell, N. S., Perry, S. J., Maertz, C. P., Allen, D. G., \& Griffeth, R.W. (2013). All you need is... resources: The effects of justice and support on burnout and turnover. Human Relations, 66(6), $759-782$.

Colquitt, J. A. (2012). Organizational justice. In S. W. J. Kozlowski (Ed.). Oxford library of psychology. The Oxford handbook of organizational psychology, 1, 526-547. New York, NY, US: Oxford University Press.

Colquitt, J. A., LePine, J. A., Piccolo, R. F., Zapata, C. P., \& Rich, B. L. (2012). Explaining the justiceperformance relationship: Trust as exchenge deepener or trust as uncertainty reducer? Journal of Applied Psychology, 97(1), 1-15.

De Jong, J., \& Den Hartog, D. (2010). Measuring innovative work behaviour. Creativity and Innovation Management, 19(1), 23-36.

Ghosh, D., Sekiguchi, T., \& Gurunathan, L. (2017). Organizational embeddedness as a mediator between justice and in role performance. Journal of Business Research, 75, 130-137.

Goh, S. K., \& Sandhu, M. S. (2014). The influence of trust on knowledge donating and collecting: An examination of Malaysian Universities. Journal of International Education Studies, 7(2), 125136.

Gong, Y., Cheung, S., Wang, M., \& Huang, J. (2012). Unfolding the proactive process for creativity: Integration of the employee proactivity, information exchange, and psychological safety perspectives. Journal of Management, 38(5), 16111633.

Hair, J. F., Black, W. C., Babin, B. J., \& Anderson, R. E. (2010). Multivariate data analysis: A global perspective. NJ: Prentice Hall Upper Saddle River.

Hallin, C.A., \& Marnburg, E. (2008). Knowledge management in the hospitality industry: A review of empirical research. Tourism Management, 29(2), 366-381.

Hammond, M. M., Neff, N. L., Farr, J. L., Schwall, A. R., \& Zhao, X. (2011). Predictors of individual-level innovation at work: A meta-analysis. Psychology of Aesthetics, Creativity, and the Arts, 5, 90-105.

Harjanti, D., \& Noerchoidah. (2017). The effect of social capital and knowledge sharing on innovative capability. Jurnal Manajemen dan Kewirausahaan, 19(2), 72-78.

Harrington, R. J., \& Ottenbacher, M. C. (2011). Strategic management: An analysis of its representation and focus in recent hospitality research. International Journal of Contemporary Hospitality Management, 23(4), 439-462.
He, W., \& Wei, K. K. (2009). What drives continued knowledge sharing? An investigation of knowledge-contribution and-seeking beliefs. Decision Support Systems, 46(4), 826-838.

He, H., Zhu, W., \& Zheng, X. (2014). Procedural justice and employee engagement: Roles of organizational identification and moral identity centrality. Journal Business Ethics, 122, 681695.

Heidari, D. S. A., \& Saeedi, N. (2012). Studying the role of organizational justice on job satisfaction (Case study: An Iranian company). Journal of Basic and Applied Scientific Research, 2(7), 6459-6465.

Hon, A. H. Y. (2011). Enhancing employee creativity in the Chinese context: The mediating role of employee self-concordance. International Journal of Hospitality Management, 30(2), 375-384.

Hsu, L., \& Wang, H. (2015). Exploring the effects of organizational justice on employees' innovative behavior in Hospitality Industry from the aspect of organizational support. Revista de Cercetare si Interventie Sociala, 49, 113-126.

Hu, M. L. M., Horng, J. S., \& Sun, Y. H. C. (2009). Hospitality teams: Knowledge sharing and service innovation performance. Tourism Management, 30(1), 41-50.

Karkoulian, S., Al Harake, N., \& Messarra, L. C. (2010). Correlates of organizational commitment and knowledge sharing via emotional intelligence: An empirical investigation. The Business Review, 15(1), 89-96.

Karkoulian, S., Assaker, G., \& Hallak, R. (2016). An empirical study of 360-degree feedback, organizational justice, and firm sustainability. Journal of Business Research, 69, 1862-1867.

Kerwin, S., Jordan, J. S., \& Turner, B. A. (2015). Organizational justice and conflict: Do perceptions of fairness influence disagreement? Journal of sport management review, 18, 384-395.

Kim, S. L., Han, S., Son, S. Y., \& Yun, S. (2017). Exchange ideology in supervisor-subordinate dyads, LMX, and knowledge sharing: A social exchange perspective. Asia Pacific Journal of Management, 34(1), 147-172.

Kim, T., \& Lee, G. (2010). Examining social capital and knowledge sharing as antecedents of service innovativeness and business performance in the hotel industry: An application of the resourcebased view (RBV) theory. Journal of Tourism Sciences, 34(7), 13-36.

--- (2012). A modified and extended Triandis model for the enablers-process-outcomes relationship in hotel employees' knowledge sharing. The Service Industrial Journal, 32(13), 20592090. 
(2013). Hospitality employee knowledge sharing behavior in the relationship between goal orientations and service innovative behavior. Journal of Hospitality Management, 34, 324-337.

Kim, W. \& Park, J. (2017). Examining structural relationships between work engagement, organizational procedural justice, knowledge sharing, and innovative work behavior for sustainable organizations. Sustainability, 9, 1-16.

Krizaj, D., Brodnik, A. \& Bukovec, B. (2014). A tool for measurement of innovation newness and adoption in tourism firms. International Journal of Tourism Research, 16(2), 113-125.

Kumar, N., \& Che Rose, R. (2012). The impact of knowledge sharing and Islamic work ethic on innovation capability. Cross Cultural Management, 19(2), 142-165.

Larson, M. (2011). Innovation and creativity in festival organizations. Journal of Hospitality Marketing \& Management, 20, 287-310.

Li, A., \& Cropanzano, R. (2009). Fairness at the group level: Justice climate and intra unit justice climate. Journal of Management, 35(3), 564-599.

Magnini, V. P. (2008). Practicing effective knowledge sharing in international hotel joint ventures. International Journal of Hospitality Management, 27, 249-258.

Mat, D., Yaacob, N. A., \& Melhem, S. B. (2016). Knowledge sharing effect on HRM practices and organizational innovation among Malaysia's Four and Five Star Hotel. International Business Management, 10(16), 3580-3590.

McShane, S., \& Glinow, M. A. (2010). Organizational behavior: Emerging knowledge and practice for the real world, Fifth Edition. New York: McGraw-Hill.

Momeni, M., Ebrahimpour, H., \& Ajirloo, M. B. (2014). Surveying the impact of inferential organizational justice on innovative work behavior. Singaporean Journal of Business Economics and Management Studies, 2(9), 1-8.

Mura, M., Lettieri, E., Radaelli, G., \& Spiller, N. (2013). Promoting professionals innovative behaviour through knowledge sharing: The moderating role of social capital. Journal of Knowledge Management, 17(4), 527-544.

Ouyang, Z., Sang, J., Li., P., \& Peng, J. (2015). Organizational justice and job insecurity as mediators of the effects of emotional intelligence on job satisfaction: A study from China. Journal of personality and individual differences, 76, 147-152.

Park, H., Son, S. Y., Lee, S., \& Yun, S. (2009). Organizational justice and knowledge sharing. International Journal of Business Research, 9 (4), 180-185.
Safa, N. S., \& Solms, R. V. (2016). An information security knowledge sharing model in organizations. Computers in Human Behavior, 57, 442451.

Shin, Y., Du, J., \& Choi, J. N. (2015). Multi-level longitudinal dynamics between procedural justice and interpersonal helping in organizational teams. Journal of business psychology, 30, 513528.

Simmons, A. L. (2011). The influence of openness to experience and organizational justice on creativity. Creativity Research Journal, 2(1), 9-23.

Slåtten, T., Svensson, G. \& Sværi, S. (2011). Empowering leadership and the influence of a humorous work climate on service employees' creativity and innovative behaviour in frontline service jobs. International Journal of Quality and Service Sciences, 3(3), 267-284.

Streicher, B., Jonas, E., Maier, G. W., \& Frey. D. (2012). Procedural justice and innovation: Does procedural justice foster innovative behavior? Journal Psychology, 3(12A), 1100-1103.

Suliman, A., \& Khatairi, M. (2013). Organizational justice, commitment and performance in developing countries: The case of UAE. Journal Employee Relation, 35(1), 98-115.

Tajeddini, K. (2010). Effect of customer orientation and entrepreneurial orientation on innovativeness: Evidence from the hotel industry in Switzerland. Tourism Management, 31(2), 221-231.

Tangaraja, G., Rasdi, R. M., Ismail, M., \& Samah, B. A. (2015). Fostering knowledge sharing behaviour among public sector managers: A proposed model for the Malaysian public service. Journal of Knowledge Management, 19(1), 121-140.

Thurlings, M., Evers, A. T., \& Vermeulen, M. (2015). Toward a model of explaining teachers' innovative behavior: A literature review. Review of Educational Research, 85, 430-471.

Tohidinia, Z., \& Mosakhani, M., (2010). Knowledge sharing behaviour and its predictors. Industrial Management \& Data Systems, 110(4), 611-631.

Tsai, C. Y., Horng, J. S., Liu, C. H., \& Hu, D. C. (2015). Work environment and atmosphere: The role of organizational support in the creativity performance of tourism and hospitality organizations, International Journal Hospitality Management, 46, 26-35.

Urbaach, N., \& Ahlemann, F. (2010). Structural equation modeling in information systems research using Partial Least Square. Journal of Information Technology Theory and Application, 11(2), 5-40. 
Usmani, S., \& Jamal, S. (2013). Impact of distributive justice, procedural justice, interactional justice, temporal justice, spatial justice on job satisfaction of banking employees. Review of Integrative Business and Economics Research, 2(1), 351-383.

Wang, S., \& Noe, R. A. (2010). Knowledge sharing: A review and directions for future research. Human Resource Management, 20, 115-131.

Welschen, J., Todorova, N. \& Mills, A. (2012). An investigation of the impact of intrinsic motivation on organizational knowledge sharing. International Journal of Knowledge Management, $8(2), 23-42$.

Yang, J. T., (2010). Antecedents and consequences of knowledge sharing in international tourist hotels. International Journal of Hospitality Management, 29(1), 42-52.

Yesil, S., \& Dereli, F.S. (2013). An empirical investigation of the organizational justice, know- ledge sharing and innovation capability. Technological and Innovation Management, 75, 217 225.

Young, L. D. (2012). How to promote innovative behavior at work? The role of justice and support within organizations. Journal of Creative Behavior, 46(3), 220-243.

Yuan, F., \& Woodman, R. W. (2010). Innovative behavior in the workplace: The role of performance and image outcome expectations. Academy of Management Journal, 53, 323-342.

Zhang, Y. \& Begley, T. (2011). Perceived organizational climate, knowledge transfer and innovation in China-based research and development companies. The International Journal of Human Resource Management, 22 (1), 34-56.

Zhang, Y., LePine, J. A., Buckman, B. R., \& Wei, F. (2014). It's not fair... or is it? The role of justice and leadership in explaining work stressor-job performance relationships. Academy of Management Journal, 57(3), 675-697. 


\section{Appendix}

\section{Measures of Constructs}

\section{Procedural Justice}

1 The management assesses the supervisor based on established procedures.

2 In the decision-making process, the representation of supervisors is sufficient.

3 The implementation of decisions is executed consistently on the supervisors affected by the results of the decision.

4 In the decision-making process in the hotel chain, management makes policies based on complete and accurate information.

5 The supervisor gets the opportunity to propose improvements to ineffective procedures.

6 Supervisor gets the opportunity to express their opinions during the decision-making process.

7 In the decision-making process, management listens to the supervisor's views on what will be decided.

1 I ask my colleagues about their abilities when I want to learn something.

2 I am happy to get information from colleagues from within my department.

3 I am happy to get information from colleagues outside my department.

4 I ask colleagues to teach the skills they have.

5 I ask colleagues in the department to teach their expertise.

6 When my co-worker has certain experiences, I ask them to tell me.

7 My company uses communication tools that support the collection of information and knowledge.



